sanibation generally, such a condition of things and combination of evil influences were surely not much less perilous than a sudden change of temperature or an east wind. And there is no certainty that Warwickshire was specially exposed to east winds in the end of April. Chaucer writes :-

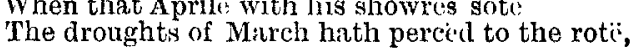

When Zephyrus eek with his swete breth."

Besides, Dr. Hall mentions in his "Select Observations," published by Cooke, that the very year after his illustrious father-in-law died a "new fever" was raging in the town, and might possibly have begun in the place the year before: for it is matter of unspeakable regret that the notes of this physician begin most tantalisingly in the year after Shakespeare's death. What this "new fever" was-whether typhoid, epidemic pneumonia, influenza, or some modified phase of malarial or rheumatic fever-it is impossible to say from the evidence at command.

The only other link in the chain of this "drunk and dying" theory is that of the look of "ineffable sadness" which has been detected in the bust of the poet. Whoever discovered this melancholic aspect of the Stratford bust before? And even if it were found to exist, would it be exceptionally wonderful, rare, or strange, or necessarily suggestive of death from pneumonia? There is no doubt whatever that the author of "Hamlet" during his lifetime bore many a time and of a look of "ineffable sadness" in his noble face without suffering from pneumonia. And I have certainly never known a physician who could diagnose death from pneumo-paresis by looking at the expression on the face of a cadaver; such quick.sighted divination has but rarely reached the schools as yet, and must be limited to a very few specially gifted medical seers, And surely pneumonia is not the only cause of a look of sadness in dead faces. The eyes have a trick of seeing what the mind is wishful to see; and the primitive makers of the original cast and the humble sculptor of the Stratford bust copied from it, could not have dared to hope that the double operation would result in such perfect and minutsly accurate work as your American writer supposes he has found it to be. Altogether, this point of the pneumonic physiognomy, true to a certain extent as it may be, which has been gathered from a probably imperfect, though generally reliable, bit of sculpture, is much too refined, artificial, and forced for ordinary mortals. I am pretty sure that, like the "deep intoxication," it has no real existence.

I cannot see, therefore, that the writer in the New York Medical Record has at all made out his case, however ingenious his hypothesis may be. It is quite possible that Shakespeare died of pneumonia, just as it is equally possible that he may have died of typhoid fever, rheumatic fever, bronchitis, influenza, or malarial poisoning of some kind, for we have no idea whatever as to the length of his illness. Instead of a "jury of the present day," provided they had an intelligent acquaintance with the poet's character and works, reasonably finding a verdict of " Death from pneumonia," I have no doubb whatever, if the evidence were fully given and severely examined, that their verdict would still be "Canse of death unknown." I have merely to add that your correspondent Mr. Foy, who, like myself, disagrees with the new suggestion, though for a somewhat different and, in my opinion, erroneous reason, has not been altogether accurate in his statements. He mentions that the period covered by Ward's diary, 1648 to 1679 , was that "in which Shakespeare enjoyed his leisure and died ;" while of course the fact is that that period was from 1613 to 1616. And again, instead of Dr. Hall being an "important witness," as he might well have been, it is a preeminently lamentable fact that he is silent about the illness and death of his now world.renowned friend and patient. For it cannot be doubted that he was the medical attendant in Shakespeare's last illness. But no hint is to be found in his "Select Observations" bearing on the case of his father-in-law; possibly his notes previous to 1617 have been lost. So that any diagnosis drawn from his notes must be entirely imaginary or a hypothetical inference from some vague facts of the family history. It is true that among the rank-and-file of the profession in those days the term "pleurisy" was employed to designate most forms of inflammatory chest disease ; but among the better educated and cultured of the physicians, among whom Dr. Hall has claims to be reckoned, the affection known as "peri-pneumonia" must have been familiar, as it is distinctly recognised, described, and named by the old medical writers who were their authorities. The word "fever" also covered many undiagnosed inflammatory diseases as well as the specific and zymotic ones.

I am, Sirs, yours truly, D. Beattre BaIN, M.D.

Airlie-place, Dundee, Dec. 21st, 1891

\section{ANTISEPTICS IN OPHTHALMIC SURGERY.}

\section{To the Editors of The LANCET.}

SIRS,-In to-day's issue of THE LANCET there appears a letter from Mr. Bullar in which he throws considerable doubt upon the benefits resulting from the use of antiseptics in ophthalmic surgery, and in support of his opinion he refers to an experiment in which, in spite of the use of antiseptics and every care, the rabbit's eye-the subject of his researches-very soon decomposed. But, Sirs, this experiment; to my mind, proves nothing at all; he is dealing with dead matter, tissue absolutely devoid of resisting power through any vitality of its own ; and, curiously, he describes this experiment immediately after having mentioned Dubief's interesting paper, in which is demonstrated the practical impossibility of rendering an eye operation aseptic-i.e., that, after repeated washings and treatment with antiseptics, germs capable of multiplying and setting up mischief could still be discovered in the tissues by the microscope. Then what, under such conditions, is it that allows of a successful result in any case? Should they not all fail? Is it not the inherent vitality of the tissues, the superior fighting power of the leucocytes, or other resisting forces, which prevent such a disastrous termination to every operation? But may not antiseptics have something to do with the successful result; may they not act as the skirmishers and sharpshooters in less mimic warfare, crippling the germs and making them very sick, so that they may more readily receive the coup de grace at the hands of the lencocytes \&c., or, at any rate, be rendered powerless to make a breech in their opponents' bulwarks? Is it not a fact that both pan-ophthalmitis and plastic iritisthose two bugbears after extraction of cataract, and both, in all probability, septic in origin-are decidedly less frequent than before the ase of antiseptics? Do not the records and experience of our metropolitan ophthalmic hospitals, situated as they are in places where germs most do congregate, bear out this statement? I think so. Because many operations are successful, though carried out under other than antiseptic principles, it does not follow that antiseptics are of no use ; they may, perhaps, be only really necessary in an odd case or two in which the inherent resisting power of the tissues is not great enough unaided to wage a successful war with their microscopic foes; but as it is impossible to know such cases from others, it behoves us to treat all with equal care, then we can have nothing to reproach ourselves with. Even a good swimmer would not feel any the less secure in either smooth or rough water with a reliable swimming belt round his chest.

I am, Sirs, yours faithfully,

S. JOHNSON TAYLOR, M.B., M.R.C.S.

Prince of Wales-road, Norwich, Dec. 19th, 1891

\section{"ACUTE RHEUMATISM AND THE TEMPORO. MAXILLARY JOINT."}

\section{To the Editors of THE LANCET.}

SIRS,-In reply to Mr. Lane's letter in your issue of to-day, I would say that when I exposed (what I represented to be) his premisses and upset his conclusions, I did not, as he suggests, do it unintentionally. To misstate an opponent's argument is bad, but to misquote his statements is worse, and Mr. Lane has twice been guilty of this offence ; in his first extract from my letter he writes " and even with rheumatic arthritis" instead of "and never \&c." This, though, may be a clerical error, and as such I leave it; but when in his next quotation he writes, "why should that joint be affected alone" instead of "why should that joint never be affected alone" there can, it is plain from the context, be no such error as I have supposed above. I feel too that he 
must have read my letter so carelessly as almost to justify me in not replying, for not only does he quote the sentence wrong, but he makes it refer to rheumatoul arthritis instead of acute rheumatism, as in the original it most clearly does. This correction is sufficient answer to that part of the letter following and founded on the above misstatement. I fear I am intensely dull, but I cannot grasp the line of reasoning as to comparative and complete degrees of tendency to affection of certain joints. If my logic was "pre-Baconian," Mr. Lane's may be termed ultra-Baconian. That I have misstated Mr. Lane's argument I quite deny. I repeat that in his first letter he practically said " that because the temporomaxillary joint is often affected with rheumatoid arthritis, and never with rheumatic arthritis, therefore it aloue can never be affected with acute rheumatism." For he wrote: "The only [the italics are mine] connexion which is in my mind allowable is between affection of this joint and rheumatic arthritie." The only proof he adduces in support is the subsequent part of his letter, where he states thav according to his observation the temporo-maxillary joint never is affected with rheumatic arthritis, and that it is very frequently the seat of rheumatoid arthritis-so of ten, in fact, that " the disease may be diagnosed with comparative safety by terming it rheumatoid arthritis should the temporomaxillary joint be at all affected." I first wrote pointing out that $I$ thought your correspondent had not sufficient grounds to upset Dr. Gallipe's diagnosis, as the statements in his first letter were all he brought forward to support his contention, and as there was evidence in Dr. Gallipe's report against rheumatoid arthritis and in favour of acute rheumatism, I can only repeat what I first said. In answer to Mr. Lane's last paragraph, his letter is certainly quite "enough," though not right enough, to show me any chimera of my own creation.- I am, Sirs, your obedient servant,

Freshford, Dec. 26th, 1891. Charles E. S. Flemming.

\section{To the Editors of THE LANCET.}

SIRs,-Apropos of some recent communications in your widely read journal on the above subject-Oct. 24 th and Nov. 14th, 1891, - I would like to add the following peculiar case, also some few remarks and deductions from some recent experience, to me appearing to add weight to the microbic theory of the origin of the disease. A sailor, aged twentyseven, employed as a guard over unruly and incorrigible apprentices, was suddenly taken ill in the night with shiverings and general pains. He presented himself for treatment on the following morning. He had only a moderately high temperature $\left(1015^{\circ}\right.$ ), complained of pains in his back, neck, and principally in his jaws. Upon examination the temporomaxillary joint was very tender, swollen, and mastication or movement of the jaws was impossible. He was known to be living under insanitary conditions most of the time, and there was suspected serious disease, possibly tetanus. He was isolated and placed under conditions of extreme quiet and careful management. On the third day the joints of the lower extremities manifestly became involved, the $j a w s$ could be opened elightly, and as no spasm of muscle or nervous phenomena occurred, the case was recorded as one of ordinary acute rheumatism and treated accordingly. It was next discovered that the patient had gonorrhoea, and the affection was thus finally placed in its proper category. It went on for a month, as a more or less painful inflamma. tory and septic affection of the ligamentous tissues of the body. The temporo-maxillary joint and contiguous structures, the hip and knee-joints, caused most anxiety and pain, and in the order named. The temperature averaged $102^{\circ}$, with a daily evening rise ; the perspirations were constant; the urine not changed beyond being concentrated; and the pains exquisite, and requiring large amounts of narcotics and anodynes to keep him from crying out constantly. He was treated with alkalies, salicylates, quinine, and hot baths, the urethritis receiving proper attention. After using large doses of morphia, bromides, chloral, \&e., with only partial success, to relieve his acute sufferings, we found that by using the ext. cannabis indica, in half-grain doses, for several hours, and at sundown a full dose of sulphonal in a large draught of hot water, painless sleep was procured. Now this was a case produced by an antecedent specific urethritis withont a doubt I have seen many cases of what we call "gonorrhoeal rheumatism," but not one with such peculiar temporo-maxillary initiatory pronounced symptoms simulating a tetanoid condition of the neck and jaws. From some acute rheumatisms in my experience, not connected with gonorrhons, but following an ulcerated tonsillar condition, I am inclined to believe that this disease is a septic or toxic infection pure and simple, and may be in the great majority of instances so demonstrated satisfactorily. When once these structures and tissues become disordered-the fibrous tissue - the liability to future exacerbations remains. This liability is most pronounced when the disease follows a specific urethritis. The cases following ulcerated tonsils showed not much fever or general articular lesion sbeyond moderate swelling, pain, and for short periods of time; and the symptoms were promptly controlled. The striking point, and $a$ most serious element in the prognosis in these cases, is the strong tendency to lesion of the cardiac valves, notwithstanding every precaution employed. Whether a patient with vulnerable tonsils is also vulnerable at the cardiac valves is of importance, but $I$ have been struck with these cases of moderately severe acute rheumatism following ulceration of these glands in the throat, and the sequence of disease of the heart valves.

In the contention whether acute rheumatism is or is not a germ disease, or, in other words, of microbic origin, the study of such variations in the course of the disease, when apparently following, and a sequence of, purulent inflammation of a mucous membrane, is of valuable interest and importance. It is not probable, if I may hazard the thought, that a single species of bacterinm is the sole cause; or that all subjects are equally susceptible to the pathogenetic influence or toxicity of the pus organisms, or of an as yet unknown micro-organism, acting singly or in association. yet that the toxic influence is evolved during such suppurative inflamnation of mucous membrane and glandular tissue, in which the well-known pus organisms chiefly figure, is in my observation a strong probability.

I am, Sirs, yours truly,

Newport R.I., U.S. America, Dec., 1891. A. Surgeon U.S. Navy.

\section{CURIOUS ACCIDENT : A WARNING TO PRACTITIONERS}

To the Editors of The LAxCET.

SIRs, - On the evening of the 27 th ult., when about to examine an infant's chest with my binaural stethoscope. unobserved by me the left ivory ear-piece dropped off. I let the instrument go into the ear in the usual way, and the spring being somewhat strong, the uncovered end pierced my membrana tympani with a fearful crash. I shall never forget the sensation! For a moment $I$ thought an $\epsilon x p l o s i o n$ had taken place, shattering the wall on the left side of me, and for an instant felt stunned. This was followed by nausea. About a teaspoonful of blood flowed from the ear. The next morning Sir W. Dalby did me the kindness of inspecting the damaged membrane, endorsing the diagnosis expressed above, and put me on a line of treatment for the injury. C'uriously enough, to day (Dec. 29th) I described the case to a medical friend who had precisely the same accident occur to him, but without such a serious result, and, strange to say, both our stethoscopes were made by the same firm of instrument makers, and the cause of the accident was the same in each-viz, too short a screw fixing the ivory ear-piece on to the metal work. In my instrument there was only one turn and a half of "thread" to the screw, which had served well for a time, but in opening the instrument the slight hitch had apparently jerked the ear-piece off, and this falling just as $I$ was about to insert the tube into the ear escapen my notice to my cost. My object in writing this will be obvious to both practitioners and instrument makers, cautioning the one class to look to their fittings and the other to see that their workmen really do their work well. Of your usual kindness in promoting the welfare of the medical profession, both individually and collectively, I am well aware, and on this point of knowledge I beg to trespass on your valuable space in bringing this accident before my medical brethren.

London, Dec. 29th, 1891. I am, S GENER $\$ A PRACTITIONER.

\section{THE CORPUS LUTEUM.}

To the Editors of THE LANCET.

SIRS, - I do not know whether my friend Dr. Robert Lee will be inclined to place me in the rank as one who has had 